\title{
The Identification and Classification of Arid Zones through Multicriteria Evaluation and Geographic Information Systems-Case Study: Arid Regions of Northwest Mexico
}

\author{
Lidia Yadira Perez-Aguilar (D), Wenseslao Plata-Rocha*(D), Sergio Alberto Monjardin-Armenta (D), \\ Cuauhtémoc Franco-Ochoa (D) and Yedid Guadalupe Zambrano-Medina (D)
}

Citation: Perez-Aguilar, L.Y.; Plata-Rocha, W.; Monjardin-Armenta, S.A.; Franco-Ochoa, C.;

Zambrano-Medina, Y.G. The Identification and Classification of Arid Zones through Multicriteria Evaluation and Geographic Information Systems-Case Study: Arid Regions of Northwest Mexico ISPRS Int. J. Geo-Inf. 2021, 10, 720 . https://doi.org/10.3390/ijgi10110720

Academic Editor: Wolfgang Kainz

Received: 6 August 2021

Accepted: 15 October 2021

Published: 26 October 2021

Publisher's Note: MDPI stays neutral with regard to jurisdictional claims in published maps and institutional affiliations.

Copyright: (C) 2021 by the authors Licensee MDPI, Basel, Switzerland. This article is an open access article distributed under the terms and conditions of the Creative Commons Attribution (CC BY) license (https:// creativecommons.org/licenses/by/ $4.0 /)$.
Facultad de Ciencias de la Tierra y el Espacio, Universidad Autónoma de Sinaloa, Culiacán 80013, Mexico; lidiaperez@uas.edu.mx (L.Y.P.-A.); sa.monjardin12@info.uas.edu.mx (S.A.M.-A.); cfrancoo@uas.edu.mx (C.F.-O.); Yedidzambrano@uas.edu.mx (Y.G.Z.-M.)

* Correspondence: wenses@uas.edu.mx; Tel.: +521-667-303-7848
Abstract: Arid and semiarid regions are geographic units that cover approximately $43 \%$ of the earth's surface worldwide, and conditions of extreme drought and reduced vegetation cover predominate in these regions. In Mexico, arid and semiarid ecosystems cover more than half of the territory, with desertification, mainly caused by anthropogenic activities and climatic events, as the main problem in these regions. The present research aimed to assess, identify, and classify arid and semiarid zones by employing a methodology based on multicriteria evaluation analysis (MCA) using the weighted linear combination (WLC) technique and geographic information systems (GIS) in the hydrological administrative regions (HARs) of the North Pacific, Northwest, and Baja California Peninsula, located in Northwest Mexico. Data related to aridity, desertification, degradation, and drought were investigated, and the main factors involved in the aridity process, such as surface temperature, soil humidity, precipitation, slopes, orientations, the normalized difference vegetation index (NDVI), and evapotranspiration, were obtained. For the standardization of factors, a fuzzy inference system was used. The weight of each factor was then determined with the analytical hierarchy process (AHP). To delimit arid regions, the classification of arid zones proposed by the United Nations Environment Program (UNEP) was used, and the result was an aridity suitability map. To validate the results, the sensitivity analysis method was applied. Quantitative and geospatial aridity indicators were obtained at the administrative hydrological level and by state. The main results indicated that semiarid and dry subhumid zones predominated, representing $40 \%$ and $43 \%$ of the surface of the study area, respectively, while arid regions represented $17 \%$, and humid regions represented less than $1 \%$. In addition, of the states for which $100 \%$ of the surface lay in the study area, it was observed that Baja California and Baja California Sur had the largest arid and semiarid zones, while subhumid regions predominated in Sonora and Sinaloa.

Keywords: aridity; arid zones; multicriteria evaluation; GIS; weighted linear combination; standardization

\section{Introduction}

Arid regions cover approximately $43 \%$ of the world's land surface [1-3]; they are characterized by limited water availability [4], increased temperature, and decreased precipitation [1]. However, despite the fact that dryland ecosystems play an important role in maintaining the balance of atmospheric components [5], most drylands are found on degraded soils [6].

A serious problem these types of ecosystems face globally is desertification caused by factors related to climatic events and human actions $[3,7,8]$ such as the use of fire, grazing, timber harvesting, and land cultivation [9].

Arid zones are regions that receive an annual precipitation of less than $200 \mathrm{~mm}$, and semiarid regions receive between 200 and $500 \mathrm{~mm}$ [3,5]. In both cases, there is a scarcity of 
water or humidity in the air and soil $[10,11]$ in addition to high solar radiation, causing high temperatures and evapotranspiration rates higher than the volume of available water [12].

In Mexico, arid and semiarid ecosystems cover more than half of the territory [13-16]. More than $40 \%$ of the national population inhabits these regions [13]. These ecosystems are being endangered by anthropogenic activities that cause desertification, such as overgrazing, land use change, deforestation, postharvest tillage, and poor soil management, causing $59 \%$ of the surface of the Mexican Republic to be desertified by soil degradation [16].

One means of obtaining indicators about the degree of aridity is the aridity index (AI), which expresses the relationship between potential evaporation (PET) and precipitation (PET/P) [17] and is widely used to estimate the hydric deficit conditions of drylands [18]. Through the usage of this index, it is possible to compare hydric conditions [19], with the potential to detect the presence and length of wet and dry periods [20] and thus quantify the deficit of precipitation in function with atmospheric water demand [21].

In these regions, it is essential to be able to determine diagnoses and prognoses that can help in the management of water resources, mainly for the evaluation of long-term water availability and the monitoring of hydrological and climatic events, which is why AI has been widely used.

AI has its beginnings in research on desertification under climate change [17] and has been widely used by the UNEP to classify aridity [6,7]. AI has also been included in several reports from the Intergovernmental Panel on Climate Change (IPCC) [8,9]. Similarly, based on the Consortium for Spatial Information (CGIAR-CSI) through the Global Aridity and PET databases [22], projections have indicated possible increases in aridity and desertification as well as serious negative impacts on natural and socioeconomic systems.

In this context, multiple criteria techniques have been widely used to make decisions in evaluating the suitability of land [23] and to solve the difficulties that decision makers encounter when handling large amounts of complex information [24].

The integration of MCE with GIS has advanced considerably thanks to two important characteristics: the capabilities in the GIS environment for the acquisition, storage, retrieval, manipulation, and analysis of data, and the ability to perform multicriteria decision making (MCDM) to combine geographic data [25].

The AHP is another structured method utilized in decision-making strategies used for complex decisions. The AHP is based on the weighting model and has been widely used in GIS to derive importance weights of criteria and establish comparisons of alternatives by pairs [24]. It can also superimpose all the standardized criteria that help to make classifications over a given area [26].

Another widely used method for evaluating the suitability of land considered appropriate for combining a set of criteria maps is WLC, which is used to standardize suitability maps, assign them relative importance weights, and combine them to obtain an overall suitability score $[25,26]$.

According to the literature reviewed, it can be argued that a contribution in this context is to identify and classify arid areas using GIS based in MCA, as these techniques have been used to define criteria involved in decision making and to determine the suitability of land in spatial planning in arid regions $[24,25,27]$.

In this vein, and given the need of different sectors to have updated maps of arid and semiarid regions in Mexico, the main objective of this study was to identify and classify arid zones in the northwest region using a methodology, which included multicriteria evaluation, a weighted linear combination technique, and geographic information systems, that can be applied at the national level.

With the purpose of determining the main factors causing aridity, environmental and territorial variables of free discharge were used (surface temperature, soil moisture, precipitation, slopes, orientations, the NDVI, and evapotranspiration), chosen based on a bibliographic review and expert opinion. 
The year of evaluation for this study was 2019, since it was the most recent year with complete data available at the time this analysis was started; however, it is possible to process the data for any year as long as there are data available.

The arid zone model was based on EMC techniques and expert opinion. Therefore, the model and its parameters needed to be validated. One way to attribute certainty to the results of the model was the application of sensitivity analysis (SA).

The techniques used in this study indicated the influence of each of the parameters on the variation of the results, individually and in association. In addition, these techniques helped simplify the model, allowing optimization of resources, time, costs, and effort involved in data acquisition and the creation of model factors [28].

\section{Materials and Methods}

\subsection{Study Area}

The study region was constituted by three HARs located in Northwestern Mexico: North Pacific, Baja California Peninsula, and Northwest, located between the geographical coordinates $32^{\circ} 39^{\prime}$ and $21^{\circ} 22^{\prime}$ North latitude and $118^{\circ} 52^{\prime}$ and $103^{\circ} 20^{\prime}$ West longitude (Figure 1).
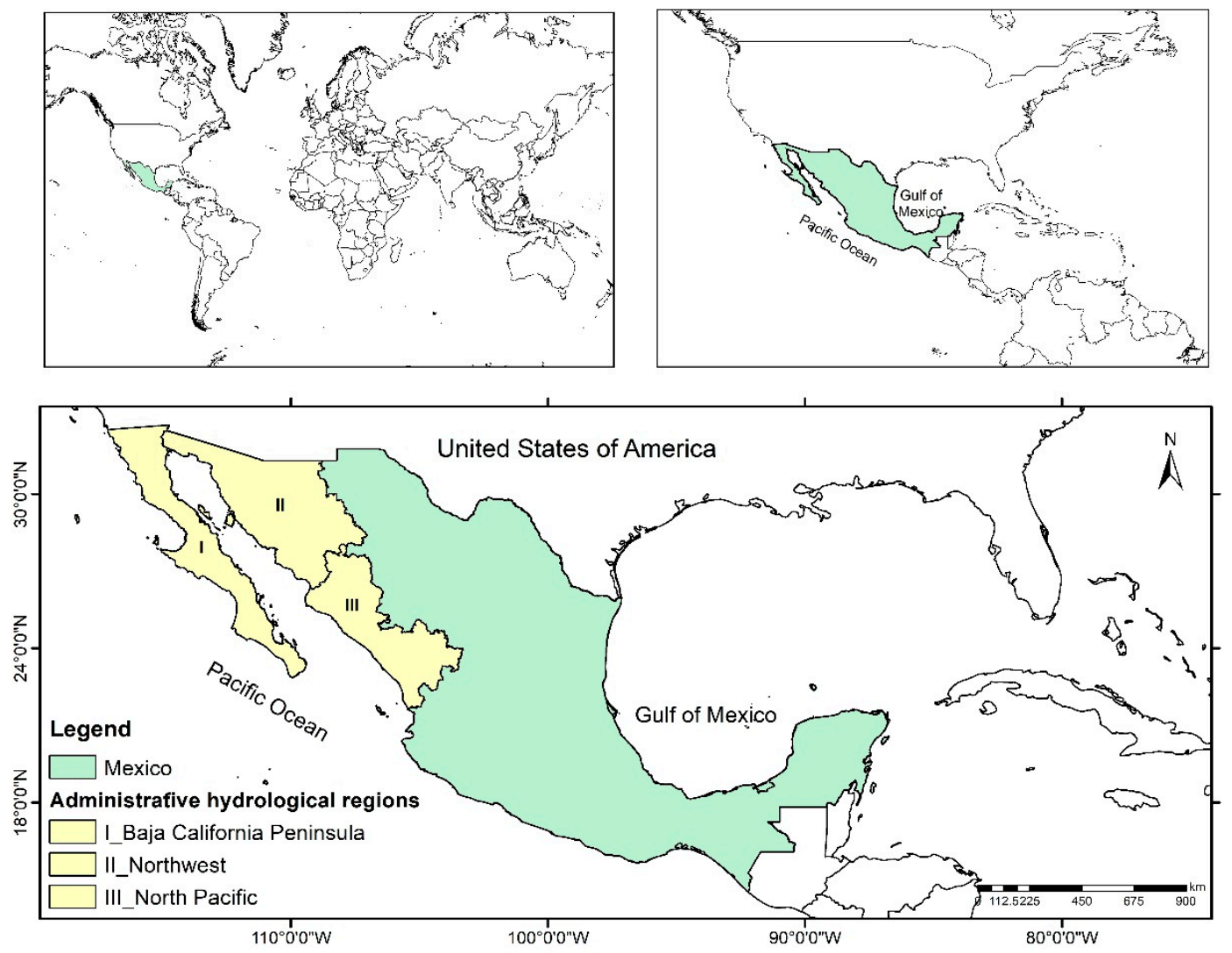

Figure 1. Study area location. Northwest Mexico: Baja California Peninsula, North Pacific, and Northwest HARs.

These regions border the Pacific Ocean to the west, the United States of America to the north, Chihuahua and Durango to the east, and Nayarit to the south. They encompass the states of Baja California, Baja California Sur, Chihuahua, Durango, Nayarit, Sinaloa, Sonora, and Zacatecas, which represent approximately $25.7 \%$ of the Mexican territory [29]. The environmental characteristics of the study region can be seen in Table 1 . 
Table 1. Environmental characteristics. Source [30-32]. Region I, Baja California Peninsula; Region II, North Pacific; Region III, Northwest.

\begin{tabular}{|c|c|c|c|c|c|}
\hline Region & $\begin{array}{c}\text { Number of } \\
\text { Municipalities }\end{array}$ & $\begin{array}{c}\text { Surface Area } \\
\text { km }^{2}\end{array}$ & Climates & $\begin{array}{c}\text { Average Annual } \\
\text { Precipitation }\end{array}$ & $\begin{array}{c}\text { Average Annual } \\
\text { Temperature }\end{array}$ \\
\hline I & 11 & 145,344 & $\begin{array}{l}\text { Semidesertic; temperate; humid and } \\
\text { temperate; desertic. }\end{array}$ & $169 \mathrm{~mm}$ & $10-24{ }^{\circ} \mathrm{C}$ \\
\hline II & 75 & 197,586 & $\begin{array}{l}\text { Dry; semidry; subhumid and } \\
\text { temperate; warm and subhumid; } \\
\text { semicold. }\end{array}$ & $368 \mathrm{~mm}$ & $20^{\circ} \mathrm{C}$ \\
\hline III & 95 & 152,013 & $\begin{array}{c}\text { Temperate subhumid; warm } \\
\text { subhumid. }\end{array}$ & $747 \mathrm{~mm}$ & $10-26^{\circ} \mathrm{C}$ \\
\hline
\end{tabular}

In the northwestern region of Mexico lies the Sonoran Desert, which is under oceanic and atmospheric influences that determine its arid climate [33]. Similarly, in Baja California Sur, very dry, semiwarm, and warm climates prevail in addition to extreme daytime temperatures, environmental dryness, and scarce precipitation [10].

\subsection{Data}

Data preparation was the first fundamental step in our aridity vulnerability analysis. Our methodology was based on GIS analysis and applied EMC techniques. The selection of variables was based on an exhaustive literature review [12,34-39] of studies on aridity, drought, and desertification (Table 2). The year 2019 was selected as the evaluation period because of the fact that, at the time of this study, it was the most current year with available data.

Table 2. Variables, data types, spatial resolutions, and data sources.

\begin{tabular}{|c|c|c|c|c|c|c|}
\hline Data (Year 2019) & Data Type & $\begin{array}{c}\text { Spatial } \\
\text { Resolution }\end{array}$ & $\begin{array}{l}\text { Temporal } \\
\text { Resolution }\end{array}$ & Units & Source & Link \\
\hline Precipitation & Raster & $4 \mathrm{~km}$ & Monthly, 2019 & Millimeters & $\begin{array}{l}\text { TerraClimate } \\
\text { Dataset }\end{array}$ & $\begin{array}{l}\text { https:/ / app.climateengine.org/ } \\
\text { climateEngine (accessed on } \\
\text { 15 October 2021). }\end{array}$ \\
\hline Temperature & Raster & $1 \mathrm{~km}$ & $\begin{array}{l}8 \text { days, annual } \\
\text { average } 2019\end{array}$ & ${ }^{\circ} \mathrm{K}$ & MODIS/USGS & $\begin{array}{l}\text { https: / / earthexplorer.usgs.gov / } \\
\text { (accessed on } 15 \text { October 2021). }\end{array}$ \\
\hline Evapotranspiration & Raster & $4 \mathrm{~km}$ & Monthly, 2019 & Millimeters & $\begin{array}{l}\text { TerraClimate } \\
\text { Dataset }\end{array}$ & $\begin{array}{l}\text { https:/ / app.climateengine.org/ } \\
\text { climateEngine (accessed on } \\
\text { 15 October 2021). }\end{array}$ \\
\hline DEM & Raster & $90 \mathrm{~m}$ & Year 2008 & Meters & SRTM & $\begin{array}{c}\text { https:/ / srtm.csi.cgiar.org (accessed } \\
\text { on } 15 \text { October 2021). }\end{array}$ \\
\hline NDVI & Raster & $500 \mathrm{~m}$ & 16 days & NDVI & MODIS/USGS & $\begin{array}{l}\text { https:/ / earthexplorer.usgs.gov/ } \\
\text { (accessed on } 15 \text { October 2021). }\end{array}$ \\
\hline Humidity & Raster & $9 \mathrm{~km}$ & Monthly, 2019 & Millimeters & FLDAS Dataset & $\begin{array}{l}\text { https:/ / app.climateengine.org/ } \\
\text { climateEngine (accessed on } \\
\text { 15 October 2021). }\end{array}$ \\
\hline Slopes & Raster & $90 \mathrm{~m}$ & Year 2008 & Degree & $\begin{array}{l}\text { Generated from } \\
\text { DEM }\end{array}$ & $\begin{array}{c}\text { https:/ / srtm.csi.cgiar.org (accessed } \\
\text { on } 15 \text { October 2021). }\end{array}$ \\
\hline Aspect & Raster & $90 \mathrm{~m}$ & Year 2008 & Degree & $\begin{array}{l}\text { Generated from } \\
\text { DEM }\end{array}$ & $\begin{array}{l}\text { https:/ / srtm.csi.cgiar.org (accessed } \\
\text { on } 15 \text { October 2021). }\end{array}$ \\
\hline
\end{tabular}

The data were standardized according to the technical specifications of the study area, i.e., a spatial resolution of $250 \mathrm{~m}$, Lambert conformal conic cartographic projection, and the same number of columns and rows. The data are described in the following paragraphs.

Precipitation. The mean annual precipitation was obtained from the TerraClimate datasets, which provided climate information derived from WorldClim data at a resolution of $4 \mathrm{~km}$ and expressed in units of millimeters $(\mathrm{mm})$. Minimum and maximum annual 
average precipitation values of 43 and $1436 \mathrm{~mm}$, respectively, for the study area were found (Figure 2a).

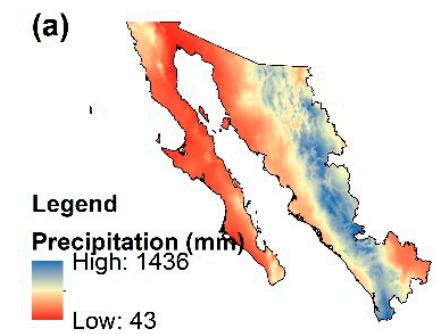

(d)

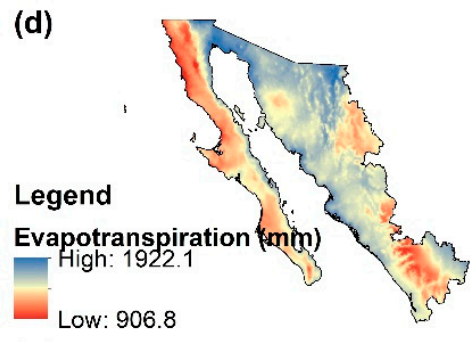

(g)
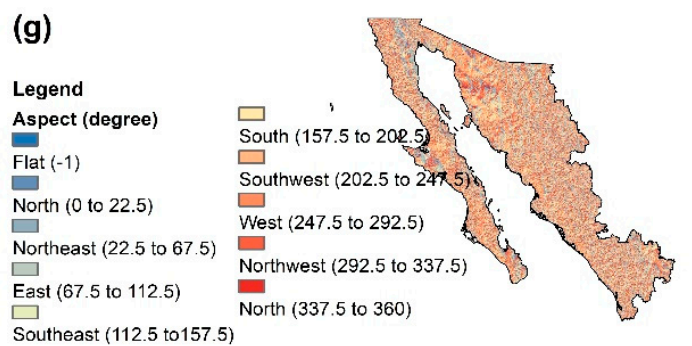

(b)

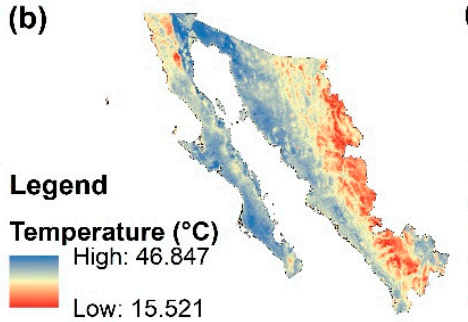

(e)

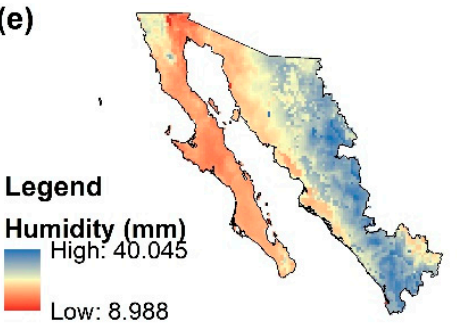

(c)

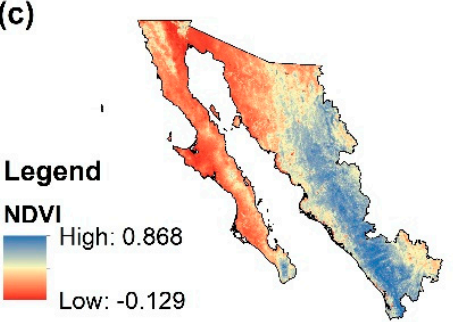

(f)

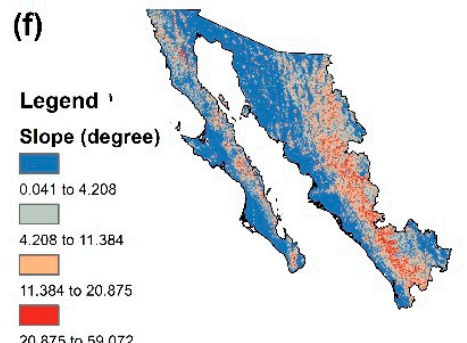

20875 to 59072

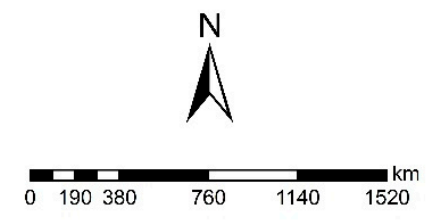

Figure 2. Variables used for the dryland model. Legend: (a) precipitation, (b) temperature, (c) NDVI, (d) evapotranspiration, (e) humidity, (f) slopes, and (g) aspect.

Temperature. The temperature map was obtained from the MOD11A2 dataset of the MODIS sensor, with a spatial resolution of $1 \mathrm{~km}$ and a temporal resolution of 8 days. Monthly average temperature maps, and subsequently the annual average temperature map, were generated. The temperature unit was converted from Kelvin to Celsius, and a scale factor of 0.02 was applied. The mean annual temperature of the study area ranged between 15.52 and 46.82 degrees (Figure $2 b$ ).

NDVI. The NDVI map was obtained from the MOD13A1 dataset from the MODIS sensor with a spatial and temporal resolution of $500 \mathrm{~m}$ and 16 days, respectively. This index has been used throughout the world because of its efficient and precise estimation and monitoring of the vegetation cover $[40,41]$. This index represents more saturation at higher levels of biomass [40]; this did not affect the analysis or the results of this investigation. Monthly mean maps and an annual mean NDVI map were generated. A scale factor of 0.0001 was applied to obtain values between -1 and 1 (Figure 2c).

Evapotranspiration. The annual mean evapotranspiration map was obtained from the TerraClimate dataset, which was calculated using the Penman-Monteith method [42] at a resolution of $4 \mathrm{~km}$ and in units of $\mathrm{mm}$. This map represented the loss of water with respect to the normal average values of rainfall. For the study area, a mean annual evapotranspiration was obtained ranging between 906 and $1922 \mathrm{~mm}$ (Figure 2d).

Humidity. The annual mean humidity map was obtained from the Land Data Assimilation System (FLDAS) dataset. Humidity here represents the amount of water found in the soil [43]. This data had a resolution of $9.6 \mathrm{~km}$ and was expressed in $\mathrm{mm}$. For the study area, minimum and maximum humidity values of 8.9 and $40 \mathrm{~mm}$, respectively, were found (Figure 2e).

Slope. This thematic layer was derived from a digital elevation model (DEM) obtained from the Shuttle Radar Topography Mission (SRTM). Slope here represents the shape of 
the relief with a resolution of $90 \mathrm{~m}$ using the spatial analysis component of GIS. The study area was nearly flat, with a maximum tilt angle of approximately $59^{\circ}$ (Figure $2 \mathrm{f}$ ).

Aspect. The aspect map was generated from the SRTM DEM, which represented each pixel according to the aspect or the direction of the slope [6] based on its orientation in degrees (from $-1^{\circ}$ to $360^{\circ}$ ) and is classified into 10 classes (Figure $2 \mathrm{~g}$ ), measured clockwise from north. Thus, a value of $0^{\circ}$ indicated that the slope was headed north, $90^{\circ}$ indicated east, $180^{\circ}$ indicated south, and $270^{\circ}$ indicated west; in addition, $-1^{\circ}$ indicated a flat area with zero slope.

\subsection{Methodology}

The methodology applied in this research to obtain arid zones established a geospatial model based on MCE, which began with a definition and the download of data necessary for processing.

Subsequently, standardization of the factors was carried out by applying a fuzzy inference system, and the level of importance of the factors was established, which entailed weighing them and obtaining the weights for each. This procedure was based on the AHP.

A WLC was used to integrate the variables. An aridity map was created, and the classification based on the AI proposed by the UNEP was applied to it to obtain a map of arid zones indicating the level of aridity for the study region (Figure 3).

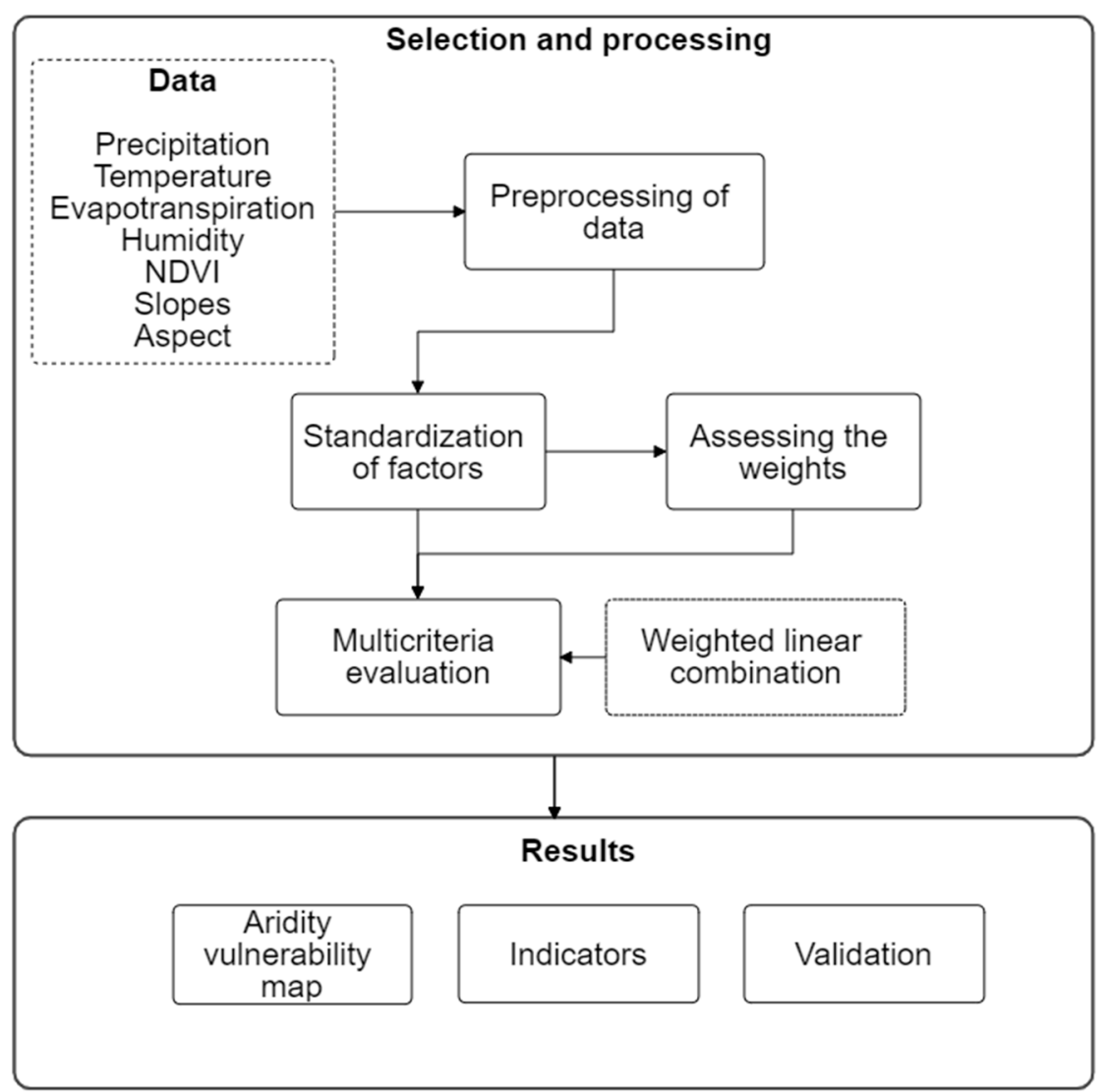

Figure 3. Methodological scheme of the process to obtain arid zones.

\subsection{Geospatial Model of Arid Zones Using EMC}

The geospatial model developed to obtain arid zones was based on the EMC and applied the WLC, which was used to determine which areas were most prone to aridity based on weighted factors and constraints $[44,45]$. For this analysis, as a restriction, the study area mask, a binary map in which a value of 0 indicated areas excluded from the analysis and a value of 1 corresponded to locations with different levels of aridity, was used. 
The integration of MCE with GIS has significantly advanced map overlay techniques for land suitability analysis. The two processes combine data evaluation (input) into a resulting decision (output), i.e., the relationship that exists between the input maps and the output map. MCE/GIS-based land use suitability assessment techniques are expressed by Equation (1):

$$
S=f(x)
$$

where $S$ is the suitability level; $x$ is the evaluation index (factors), which has a strong influence on the level of suitability; and $f(x)$ indicates the decision rule [46].

\subsubsection{Standardization of Criteria}

The standardization of factors is the process of setting the relative importance of each criterion. A pairwise comparison technique is typically used for rating and standardizing the values $[44,45,47,48]$. A fuzzy set that used a scale from 0 to 1 bytes to indicate susceptibility to aridity was applied. Table 3 shows the maximum and minimum values for each factor.

Table 3. Standardization of factors.

\begin{tabular}{ccccccc}
\hline Factor & $\begin{array}{c}\text { Minimum } \\
\text { Value }\end{array}$ & $\begin{array}{c}\text { Maximum } \\
\text { Value }\end{array}$ & Units & Function & $\begin{array}{c}\text { Minimum } \\
\text { Standardized } \\
\text { Value }\end{array}$ & $\begin{array}{c}\text { Maximum } \\
\text { Standardized } \\
\text { Value }\end{array}$ \\
\hline Precipitation & 45 & 1436 & Millimeters & Decreasing Linear & 0 & 1 \\
Temperature & 15.52 & 46.84 & ${ }^{\circ}$ C & Increasing Linear & 0 & 1 \\
NDVI & -0.12 & 0.86 & NDVI & Decreasing Linear & 0 & 1 \\
Evapotranspiration & 906.8 & 1922.1 & Millimeters & Decreasing Linear & 0 & 1 \\
Humidity & 8.98 & 40.04 & Millimeters & Decreasing Linear & 0 & 1 \\
Slopes & 0 & 144.96 & Degree & Increasing Linear & 0 & 1 \\
Aspect & 0 & 359.97 & Degree & Increasing Linear & 0 & 1 \\
\hline
\end{tabular}

Table 3 also shows the belonging function used. An increasing linear function means that higher values of the scale indicate a greater susceptibility to aridity. On the contrary, a decreasing linear function means that lower values indicate a greater possibility of extreme aridity. Through the aforementioned standardization of the variables using the fuzzy logic method, the standardized factors were determined (Figure 4).

\subsubsection{Assessing the Weights through AHP}

The AHP is the method most widely used to organize factors in a hierarchical structure [49]. Environmental and territorial factors were selected and used to identify areas vulnerable to aridity. The factors were classified based on the fundamental scale suggested by Saaty (2008) with values 1-9 (Table 4).

This method applies a pairwise combination in which only two criteria are considered at a time and thus establish a level of relative importance between each factor $[44,50]$. The AHP calculates through a comparison matrix pair and is expressed by Equation (2):

$$
\sum_{j=1}^{n} s i=1
$$

where $s i$ is the weighting for each criterion, established by taking the eigenvector corresponding to the largest eigenvalue of the matrix, and $n$ represents the number of indexes. The sum of the standardized values must be equal to 1 . 
(a)

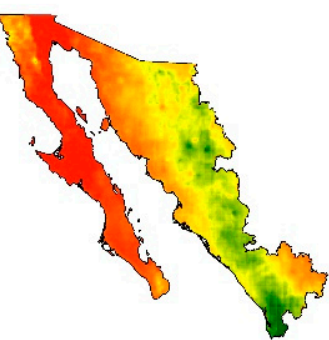

(d)

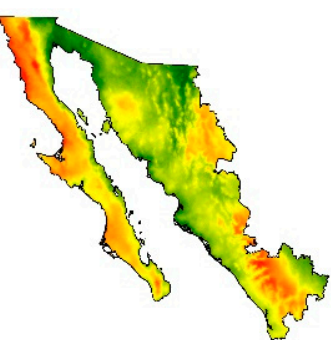

(g)

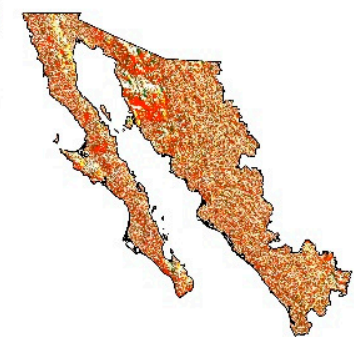

(b)

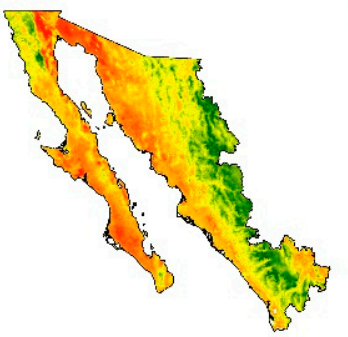

(e)

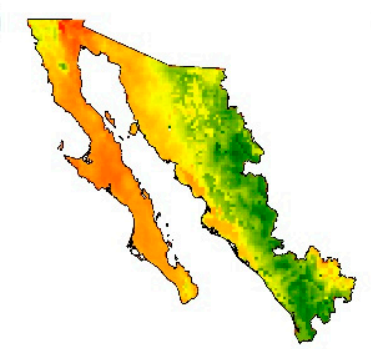

(c)

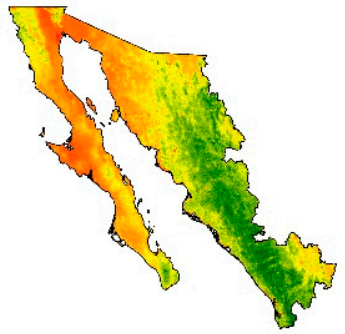

(f)

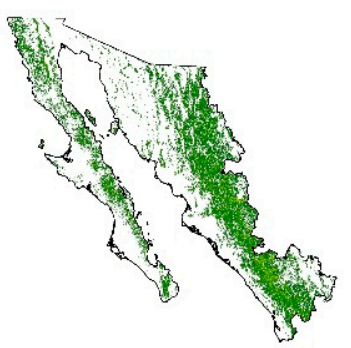

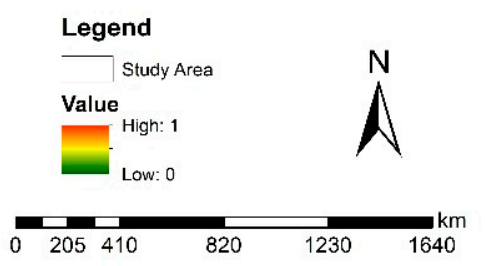

Figure 4. Factors obtained as a result of standardization. Legend: (a) precipitation, (b) temperature, (c) NDVI, (d) evapotranspiration, (e) humidity, (f) slopes, and (g) aspect.

Table 4. Fundamental AHP judgment scale with integers 1-9 [51].

\begin{tabular}{|c|c|c|}
\hline Intensity of Importance & Definition & Description \\
\hline 1 & Equal importance & Two activities contribute equally to the objective. \\
\hline 3 & Moderate importance & Experience and judgment slightly favor one activity over another. \\
\hline 5 & Strong importance & Experience and judgment strongly favor one activity over another. \\
\hline 7 & Very strong importance & $\begin{array}{c}\text { An activity is favored very strongly over another; its dominance is } \\
\text { demonstrated in practice. }\end{array}$ \\
\hline 9 & Extreme importance & $\begin{array}{l}\text { The evidence favoring one activity over another is of the highest } \\
\text { possible order of affirmation. }\end{array}$ \\
\hline $2,4,6,8$ & $\begin{array}{l}\text { Intermediate values between } \\
\text { the two adjacent judgments }\end{array}$ & A compromise is needed. \\
\hline
\end{tabular}

We noted expert opinions from various personnel: 5 from the Geomatics Laboratory of the Faculty of Earth and Space Sciences, 3 from the Autonomous University of Sinaloa, 3 from the National Forestry Commission (CONAFOR), 3 from the Ministry of the Environment and Natural Resources (SEMARNAT), and 2 from the National Commission of Arid Zones (CONAZA). A literature review was also performed. These opinions were used to determine the levels of importance and the weights of factors for the assessment of suitability for aridity such that the sum of the weights was equal to 1 .

\subsubsection{Weighted Linear Combination}

Over the past decades, multicriteria assessment methods have been proposed for GIS-based land suitability analysis. Among these, WLC is the most common for land suitability assessment and consists of combining a set of criteria maps [25]. 
Once the relative importance levels of the criteria were determined, the WLC method was used to identify arid regions. WLC calculates the suitability of a potential region using Equation (3) [44,52]:

$$
R=\sum_{j=1}^{n} w_{i} v_{i}
$$

where $R$ is the weighted variable, defined as the target; $w_{i}$ is the weight of the factor; $v_{i}$ is the weighted value of alternative $i$ of factor $j$; and $n$ represents the number of indexes. Based on Equation (3), there are four steps in WLC: selecting the index (i), providing the index value $\left(v_{i}\right)$, determining the index weight $\left(w_{i}\right)$, and employing the overlaying rule [25].

\subsubsection{Classification Criteria}

The results obtained with the aridity vulnerability map were classified based on the classification proposed by the UNEP [53,54], which defines arid regions in five classes as shown in Table 5.

Table 5. Classification of the aridity index of the UNEP.

\begin{tabular}{cc}
\hline Index & Climate \\
\hline$>0.65$ & Humid \\
$0.65-0.5$ & Subhumid-dry \\
$0.5-0.2$ & Semiarid \\
$0.2-0.05$ & Arid \\
$<0.05$ & Extremely arid \\
\hline
\end{tabular}

\subsubsection{Verification and Validation}

To attribute certainty to the results of the model, a sensitivity analysis (E-Fast) was carried out to examine in detail the components of the model and the degree of influence on the variation of the results [55].

With this application, first-order and total effect sensitivity indices can be obtained. A Monte Carlo simulation was used under one sample, taking independent input factors and a number of samples into account.

The E-Fast technique was implemented in SimLab 2.2.1, which was used to carry out the AS under the following procedure:

I. The frequency distribution of the factors and weights was established, and a variation of $\pm 25 \%$ was defined.

II. A sample of the different factors of the model was extracted (factors themselves and weights assigned to them), and the model was executed a significant number of times.

III. Finally, the values reached in the sensitivity indices of the input factors of the model were analyzed, and the results and impact were described.

\section{Results}

\subsection{Weights Obtained from the AHP}

As a result of the weighting of factors obtained by applying the AHP according to the level of importance of each criterion with respect to the others, a matrix of the final weights was obtained. This matrix is shown in Table 6. 
Table 6. Matrix of weights generated for each factor.

\begin{tabular}{cccccccccc}
\hline Factor & $\begin{array}{c}\text { Reclassified } \\
\text { Value }\end{array}$ & $\mathbf{7}$ & $\mathbf{6}$ & $\mathbf{5}$ & $\mathbf{4}$ & $\mathbf{3}$ & $\mathbf{2}$ & $\mathbf{1}$ & Weights \\
\hline Orientation & 7 & 1 & & & & & & \\
Slope & 6 & 2 & 1 & & & & & \\
Humidity & 5 & 3 & 1.5 & 1 & & & & \\
Evapotranspiration & 4 & 4 & 2 & 1.33 & 1 & & 0.03 & \\
NDVI & 3 & 6 & 3 & 2.00 & 1.5 & 1 & & 0.13 \\
Temperature & 2 & 7 & 3.5 & 2.33 & 1.75 & 1.17 & 1 & 0.19 \\
Precipitation & 1 & 9 & 4.5 & 3.00 & 2.25 & 1.5 & 1.286 & 1 & 0.22 \\
\hline
\end{tabular}

\subsection{Aridity Vulnerability Map}

Using this technique, each factor involved in the aridity process was evaluated within the established criteria, which were used as input data for each of the factors with their respective weights. In the EMC results for arid zones (Figure 5), the highest values represent the zones with the greatest vulnerability to developing arid conditions.

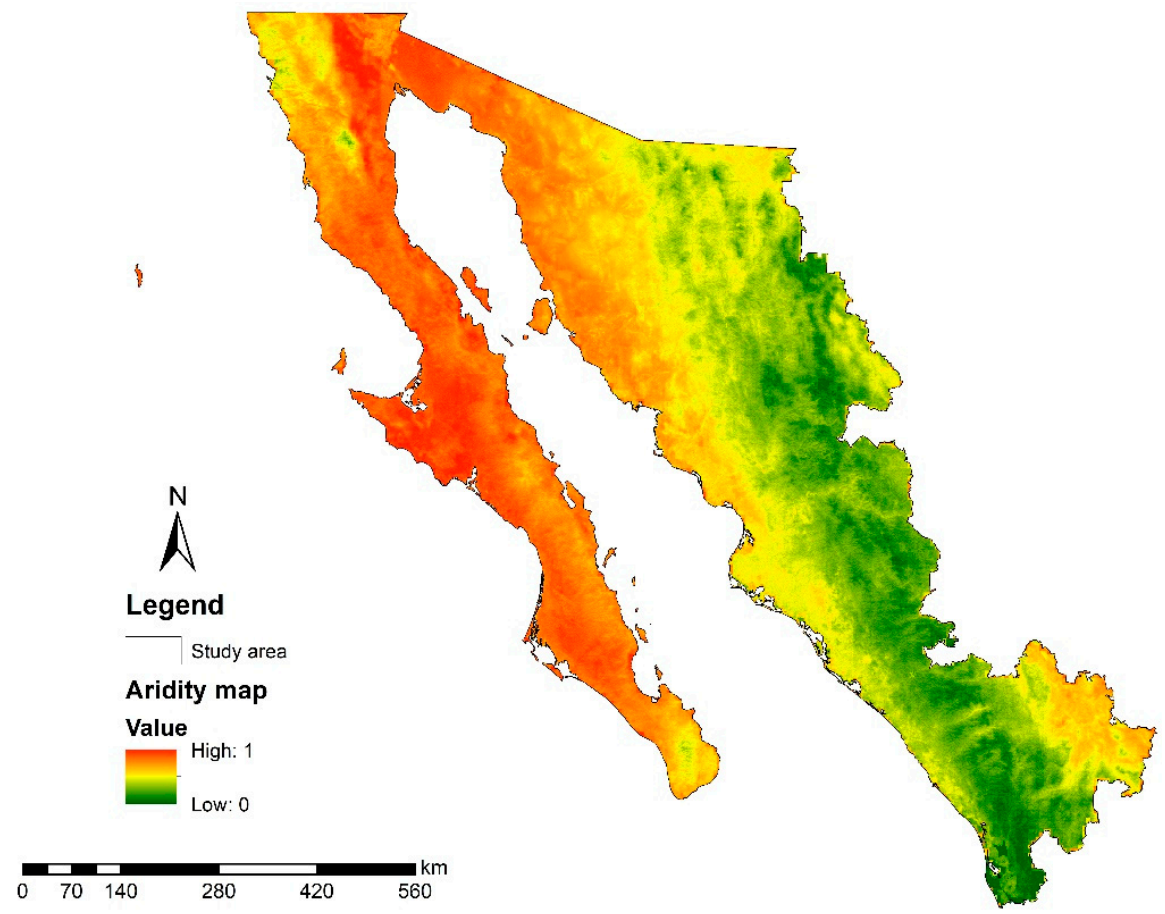

Figure 5. Aridity vulnerability map.

\subsection{Spatial Distribution of Aridity}

To obtain the map of arid zones, classifications based on the AI proposed by the UNEP were used (Figure 6). The temporal analysis and the data obtained showed that $43 \%$ of the study area consisted of dry, subhumid zones, which were mostly located in the North Pacific and Northwest HARs. This was due to the fact that these zones include the Sierra Madre Occidental, which is considered a highly diverse region in terms of vegetation, temperature, and precipitation.

Meanwhile, semiarid regions covered $40 \%$ of the surface area and were located mostly to the northwest of the Northwestern RHA, covering part of the Baja California Peninsula and North Pacific HARs, where dry and semidry climates predominated.

The arid regions covered $17 \%$ of the study area, comprising most of the Baja California Peninsula HAR and the northern part of the Northwest HAR, which are characterized by their dry and warm climate with some temperate parts. Finally, humid regions were 
represented in less than $1 \%$ of the study area and were located in the southern part of the North Pacific HAR (Figure 7 and Table 7).

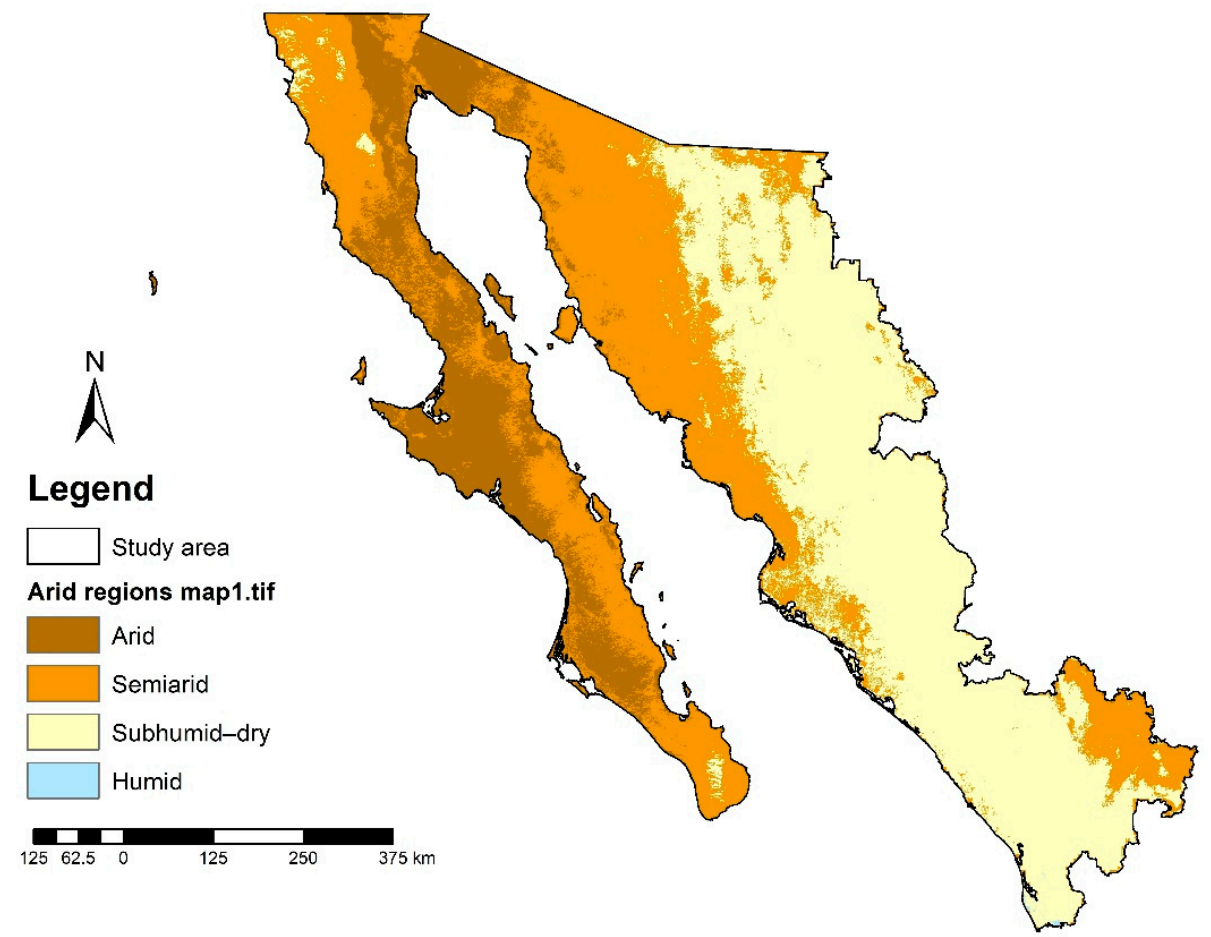

Figure 6. Arid zone map.

\section{Aridity surface area of arid regions}

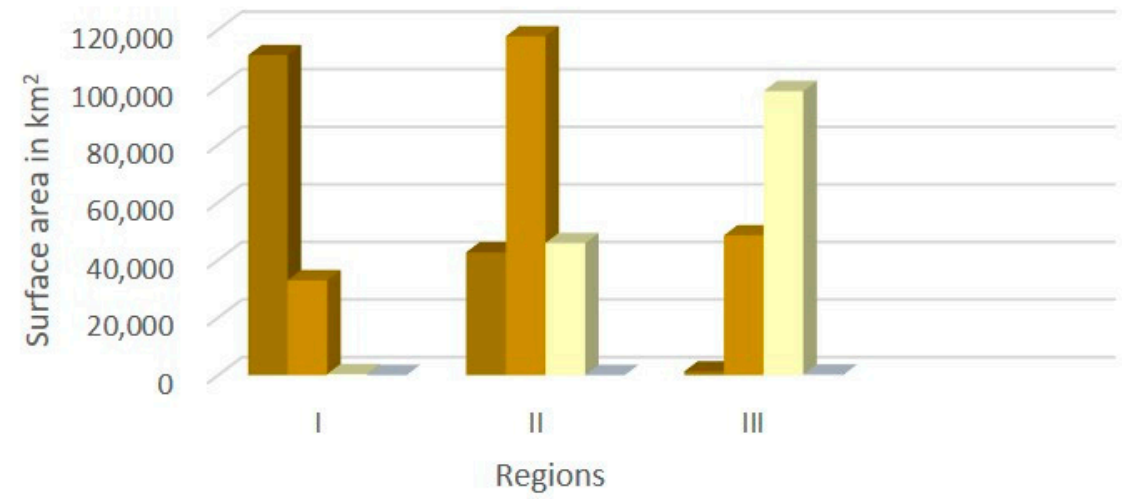

arid $\square$ Semiarid Subhumid-dry Humid

Figure 7. Graph of arid regions by percentage and study area.

Table 7. Aridity percentage and surface area of arid regions.

\begin{tabular}{|c|c|c|c|c|}
\hline \multirow[b]{2}{*}{ Region } & \multicolumn{4}{|c|}{ Regions km $^{2}$} \\
\hline & Arid & Semiarid & Subhumid-Dry & Humid \\
\hline $\mathrm{I}$ & 111,111 & 32,917 & 358 & 0 \\
\hline II & 42,635 & 117,668 & 45,829 & 0 \\
\hline \multirow[t]{2}{*}{ III } & 1279 & 48,532 & 98,609 & 158 \\
\hline & $17 \%$ & $40 \%$ & $43 \%$ & $<1 \%$ \\
\hline
\end{tabular}




\subsection{Quantitative and Geospatial Indicators in Arid Zones at a State Level}

In order to obtain quantitative and percentage information on the level of aridity, an analysis at a state level was conducted. The results indicated that the most arid zones were found in the states of Baja California and Baja California Sur, where they comprised $45 \%$ and $52 \%$ of the surface area, respectively, while the states with the largest semiarid zones were Zacatecas, Sonora, and Baja California, where semiarid zones comprised $69 \%, 54 \%$, and $51 \%$ of the surface area, respectively.

The dry subhumid zones were found mostly in Nayarit, at 93\%; Chihuahua, at $96 \%$; and Sinaloa, at $83 \%$. The only states with humid zones were Durango and Nayarit. It is important to mention that for the states of Zacatecas, Durango, Chihuahua, and Nayarit, only a portion of the total surface area was included in the study area (Table 8 and Figure 8).

Table 8. Aridity percentage at a state level.

\begin{tabular}{|c|c|c|c|c|c|c|}
\hline \multirow[b]{2}{*}{ State } & \multirow[b]{2}{*}{$\begin{array}{l}\text { Surface Area of the } \\
\text { State in the Study } \\
\text { Area }\left(\mathrm{Km}^{2}\right)\end{array}$} & \multirow[b]{2}{*}{$\begin{array}{l}\text { Surface Area of } \\
\text { the State in the } \\
\text { Study Area (\%) }\end{array}$} & \multicolumn{4}{|c|}{ Regions (\%) } \\
\hline & & & Arid & Semiarid & Subhumid-Dry & Humid \\
\hline Baja California & 73,120 & 100 & 45.92 & 51.36 & 2.72 & 0 \\
\hline Baja California sur & 71,035 & 100 & 52.04 & 46.92 & 1.05 & 0 \\
\hline Chihuahua & 54,463 & 22 & 0.15 & 3.27 & 96.58 & 0 \\
\hline Durango & 51,422 & 42 & 0.36 & 26.53 & 73.10 & 0.003 \\
\hline Nayarit & 8851.3 & 32 & 0.34 & 3.76 & 93.76 & 2.134 \\
\hline Sinaloa & 54,884 & 100 & 0.24 & 17.05 & 82.71 & 0 \\
\hline Sonora & 180,301 & 100 & 7.21 & 54.71 & 38.08 & 0 \\
\hline Zacatecas & 4458.6 & 6 & 2.12 & 69.83 & 28.05 & 0 \\
\hline
\end{tabular}

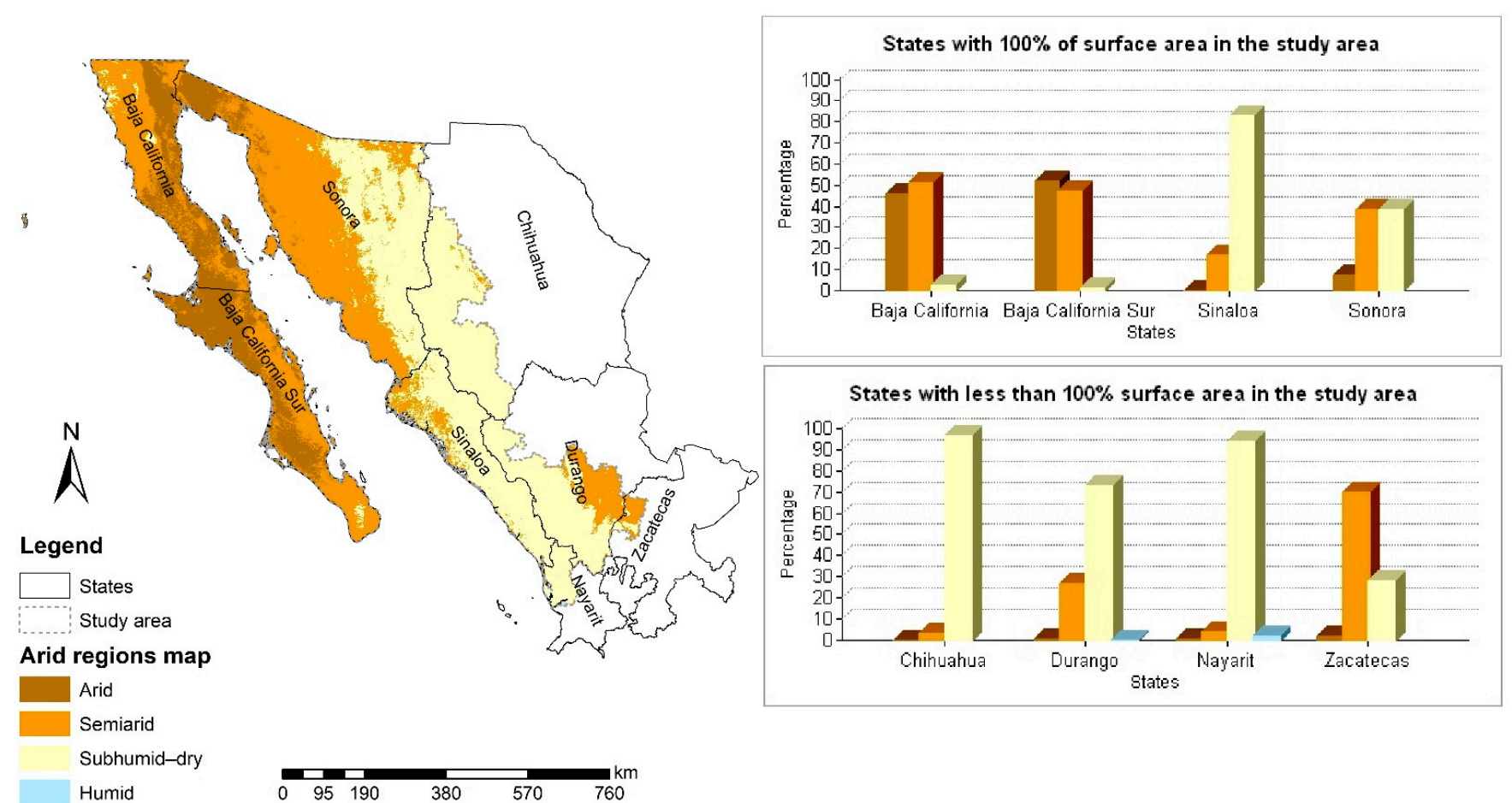

Figure 8. Map of arid zones and graphs representing the level of aridity by state.

\subsection{Validation of Results Using the Sensitivity Analysis Method}

The order of importance of the factors according to E-Fast was precipitation (47\%), NDVI $(17 \%$, and temperature $(15 \%)$. The first-order sensitivity indices of these three factors were responsible for $78 \%$ of the output variability of the model. The influence of weights 
and other factors was nearly negligible, confirming that the weights established for these factors were robust, and the addition of small variations did not influence the final results of the model.

In addition, the difference between the total effect sensitivity index (St) and the firstorder sensitivity index $(\mathrm{Si})$ is a measure of the extent to which each factor is involved in interaction with other factors in the model. For significant differences, the value should be greater than 0.2. In these models, the differences were never higher than 0.0286 (Table 9).

Table 9. Results of the E-Fast method.

\begin{tabular}{cccc}
\hline Factors & $\begin{array}{c}\text { First Order } \\
\mathbf{( S i )}\end{array}$ & $\begin{array}{c}\text { Total } \\
\mathbf{( S t )}\end{array}$ & $\begin{array}{c}\text { Difference } \\
\text { (St-Si) }\end{array}$ \\
\hline F1 Precipitation & 0.4709 & 0.4995 & 0.0286 \\
F2 Temperature & 0.1447 & 0.1548 & 0.0101 \\
F3 NDVI & 0.1669 & 0.1803 & 0.0134 \\
F4 Evapotranspiration & 0.0121 & 0.0216 & 0.0095 \\
F5 Humidity & 0.0136 & 0.0256 & 0.0120 \\
F6 Slope & 0.0016 & 0.0072 & 0.0056 \\
F7 Aspect & 0.0078 & 0.0151 & 0.0073 \\
w1 & 0.0240 & 0.0421 & 0.0181 \\
w2 & 0.0240 & 0.0342 & 0.0102 \\
w3 & 0.0289 & 0.0420 & 0.0131 \\
w4 & 0.0288 & 0.0373 & 0.0085 \\
w5 & 0.0094 & 0.0193 & 0.0099 \\
w6 & 0.0091 & 0.0174 & 0.0083 \\
w7 & 0.0008 & 0.0095 & 0.0087 \\
\hline
\end{tabular}

Therefore, the variation in the results was due to the action of the factors individually and not in combination with the others. This circumstance was corroborated through the sum of all St values, which was almost equal to 1 , showing that potential interactions present in the model had no influence on the variability of the outcome.

\section{Discussion}

Changes in temperature and precipitation in the arid regions of Northwestern Mexico favor the increased occurrence of droughts, which has great social, economic, and environmental impacts [56,57].

The main negative impacts that are related to drought events in arid regions are, in the agricultural sector, soil humidity and water deficits, a reduction of pasture and livestock, and a decrease in feed and water. In the nonagricultural sector, natural water bodies and ecosystems are affected, impacting important sectors such as municipal water supply and tourism [58].

Other problems affecting these regions are soil degradation and desertification due to the anthropogenic impacts derived from agriculture and livestock farming, which is why these ecosystems are very sensitive to climate variability and global environmental change [59].

Various studies of arid zones have used aridity indices and climatic classification in arid regions such as the Martonne [12,60] and Köppen aridity indices [61], which use precipitation and temperature as main data. Another aridity index used was proposed by the FAO [62,63], and the UNEP [64,65]; those index requires precipitation and evapotranspiration as the main data.

However, no studies to date have integrated, in addition to the variables of precipitation, temperature, and evapotranspiration, other environmental and territorial variables of equal relevance such as the NDVI, humidity, slope, and aspect, and none have applied evaluation techniques of multiple criteria to obtain a map of vulnerability to arid zones, as presented in this work. 
The results obtained from the geospatial model for arid zones applied in this study provide useful information on the different levels of aridity in the study region. The variables used proved to be ideal for integration into the aridity model at the regional level and were extrapolated to the global level.

This study enabled us to obtain multilevel indicators for arid zones. The level of aridity was determined at the pixel scale (vulnerability maps), and the impact was determined at the level of the administrative hydrological region and by state, which allowed for a more detailed understanding of the aridity problem in the northwestern region of Mexico.

This study also provided an important opportunity to advance the application of decision making through the development of a multicriteria evaluation method based on the AHP, WLC, and GIS to determine aridity suitability and classify arid regions from local to global.

The methodology developed is presented as an alternative for the continuous and dynamic study of the arid regions of the world and as support in territorial decision making and the development of public policies designed to mitigate the impact of aridity on climate change. It will also allow for effective adaptation measures to ensure human, environmental, economic, and social welfare in these regions, allowing also for great scientific progress in studies on climate change.

In future work, this methodology can be improved with more environmental data and a higher-quality resolution. Dynamic analyses of aridity can also be expanded to a national level.

\section{Conclusions}

Increases in aridity inevitably cause desertification, either indirectly through greater rainfall variability or directly through prolonged droughts. For this reason, several studies have relied on climate data to identify the global distribution of arid regions.

Such conditions endanger many places in the world, including Mexico. The severity of aridity in the present study area is high, since most of the arid regions are located on degraded soils that threaten to expand if the same land use and water resource management practices continue in these regions.

This research employed a geospatial model based on a multicriteria evaluation method that used weighted linear combination for the identification of arid and semiarid regions at the local level with global climatic, environmental, and territorial variables, which were integrated to obtain an aridity vulnerability map.

As an evaluation period, the year 2019 (the most recent year with data available at the time of this study) was used; however, this analysis can be conducted for any year as long as data are available.

The resulting map of arid zones provided relevant information on the current condition of these regions. The results showed that, in the northwestern region of Mexico, semiarid and subhumid-dry zones predominated, which is consistent with previous studies on arid zones including the Atlas of Arid Zones in Mexico [15], the INEGI climate map [66], and the map of humidity ranges of the CONABIO geoinformation portal [67].

At the administrative hydrological level, the results showed that the most affected regions with arid and semiarid conditions were found in the HARs Baja California Peninsula and Northwest. At the state level, the most affected states with such conditions were the states of Baja California, Baja California Sur, and Sonora, as well as parts of Sinaloa and Durango.

The validation of the arid zone geospatial model through the sensitivity analysis method proposed here indicated that the order of importance of the factors was perfectly suited to the model, which confirms that the precipitation, temperature, and NDVI indicators are the main factors that influence the aridity process.

It will be important to accurately model each of the variables with respect to their impacts on aridity hazards. Moreover, future studies should focus on a more detailed 
assessment that considers vegetation cover, water resources, local climates, and other socioeconomic indicators in the evaluation of aridity hazards.

Therefore, this research will be useful in helping researchers and political decision makers to contribute to the use of natural terrestrial water resources in a sustainable manner to protect the ecosystem and improve the economy of the region.

Finally, we consider it important to know the levels of aridity in the Mexican territory. Thus, the results obtained in this study could be used to establish priorities in the fight against desertification, to improve the sustainable management of hydrological and soil resources, and to guarantee food security for the population.

Author Contributions: Conceptualization, Lidia Yadira Perez-Aguilar, Wenseslao Plata-Rocha, and Sergio Alberto Monjardin-Armenta; formal analysis, Lidia Yadira Perez-Aguilar, Wenseslao PlataRocha, and Cuauhtémoc Franco-Ochoa; investigation, Lidia Yadira Perez-Aguilar, Sergio Alberto Monjardin-Armenta, and Yedid Guadalupe Zambrano-Medina; methodology, Lidia Yadira PerezAguilar, Wenseslao Plata-Rocha, and Sergio Alberto Monjardin-Armenta; writing - original draft, Lidia Yadira Perez-Aguilar, Wenseslao Plata-Rocha, and Sergio Alberto Monjardin-Armenta; writingreview and editing, Lidia Yadira Perez-Aguilar, Wenseslao Plata-Rocha, Sergio Alberto MonjardinArmenta, Cuauhtémoc Franco-Ochoa, and Yedid Guadalupe Zambrano-Medina. All authors have read and agreed to the published version of the manuscript.

Funding: This research received no external funding.

Institutional Review Board Statement: Not applicable.

Informed Consent Statement: Not applicable.

Acknowledgments: The authors thank the Faculty of Earth and Space Sciences, Autonomous University of Sinaloa, and CONACYT.

Conflicts of Interest: The authors declare that there are no conflict of interest.

\section{References}

1. FAO. Elaboración de un Programa Mundial Sobre Agricultura Sostenible en Zonas Áridas en Colaboración con el Marco Mundial Sobre la Escasez de Agua en la Agricultura en un Clima Cambiante. Available online: http://www.fao.org/3/nd412es/nd412es.pdf (accessed on 25 March 2021).

2. Quichimbo, E.A.; Singer, M.B.; Cuthbert, M.O. Characterising Groundwater-Surface Water Interactions in Idealised Ephemeral Stream Systems. Hydrol. Process. 2020, 34, 3792-3806. [CrossRef]

3. Sánchez-Cano, J.E. Desarrollo Sostenible de Zonas Áridas y Semiáridas Frente al Cambio Climático Primera; Universidad Juárez del Estado de Durango: Durango, Mexico, 2019.

4. Dunkerley, D. The Ecohydrology of Desert Environments: What Makes it Distinctive? In Encyclopedia of the World's Biomes; Michael, S., Goldstein, E., Dominick, I., DellaSala, A., Eds.; Elsevier: Amsterdam, The Netherlands, 2020; pp. 23-35.

5. Gaur, M.K.; Squires, V.R. Geographic Extent and Characteristics of the World's Arid Zones and Their Peoples. In Climate Variability Impacts on Land Use and Livelihoods in Drylands; Springer International Publishing: Berlin/Heidelberg, Germany, 2017; pp. 3-20.

6. FAO. Secuestro de Carbono en Tierras Áridas. Available online: http://www.fao.org/3/Y5738s/Y5738s.pdf (accessed on 22 February 2021).

7. IPCC. El Informe Especial del IPCC Sobre Cambio Climático y la Tierra. 2020. Available online: https://reliefweb.int/sites/ reliefweb.int/files/resources/WEB-IPCC-Land_Latin-America_Spanish_24March2020.pdf (accessed on 25 March 2021).

8. Granados-Sánchez, D.; Hernández-García, M.Á.; Vázquez-Alarcón, A.; Ruíz-Puga, P. Los Procesos de Desertificación y las Regiones Áridas. Rev. Chapingo Ser. Ciencias For. Ambiente 2013, 19, 45-66. [CrossRef]

9. ONU. Qué son las Zonas Secas? Forestería en las Tierras Secas Organización de las Naciones Unidas para la Alimentación y la Agricultura. Available online: http:/ / www.fao.org/dryland-forestry/background/what-are-drylands/es/ (accessed on 20 April 2019).

10. Diéguez, E.T.; Mancera, G.M.; Falcón, A.C.; Garibay, A.N.; Cepeda, R.D.V.; Hernández, J.L.G.; Amador, B.M. Análisis de la Sequía y Desertificación Mediante Índices de Aridez y Estimación de la Brecha Hídrica en Baja California Sur, Noroeste de México. Investig. Geográficas 2014, 85, 66-81. [CrossRef]

11. Velasco, I.; Pimentel, E. Zonificación Agroclimática de Papadakis Aplicada al Estado de Sinaloa, México. Investig. Geográficas 2010, 73, 85-102.

12. Mancera, G.M.; Diéguez, E.T.; Gómez, A.A.; Amador, B.M.; Morales, L.B.; Hernández, J.G. Calibración y Aplicación del Índice de Aridez de De Martonne para el Análisis del Déficit Hidrico Como Estimador de la Aridez y Desertificación en Zona Áridas; Universidad y Ciencia: Villahermosa, Mexico, 2010; Volume 26, pp. 51-64. 
13. Briones, O.; Búrquez, A.; Martínez-Yrízar, A.; Pavón, N.; Perroni, Y. Biomass and Productivity in Mexican arid Lands. Madera Y Bosques 2018, 24, e2401898. [CrossRef]

14. CONAFOR. La Comisión Nacional de las Zonas Áridas (CONAZA)-Innovacion Forestal. Available online: https://www.conafor. gob.mx/innovacion_forestal/?p=2177 (accessed on 25 May 2019).

15. SAGARPA and SIAP. Atlas de las Zonas Aridas de México; México, 2014. Available online: https://www.gismexico.com/azam/ azam.html (accessed on 25 May 2019).

16. SEMARNAT. El Medio Ambiente en México 2013-2014. Available online: https://apps1.semarnat.gob.mx:8443/dgeia/informe_ resumen14/03_suelos/3_3.html (accessed on 10 June 2019).

17. Greve, P.; Roderick, M.L.; Ukkola, A.M.; Wada, Y. The Aridity Index under Global Warming. Environ. Res. Lett. 2019, 14, 124006. [CrossRef]

18. D'Odorico, P.; Bhattachan, A.; Davis, K.F.; Ravi, S.; Runyan, C.W. Global Desertification: Drivers and Feedbacks. Adv. Water Resour. 2013, 51, 326-344. [CrossRef]

19. Zomer, R.J.; Trabucco, A.; Verchot, L.V.; Muys, B. Land Area Eligible for Afforestation and Reforestation within the Clean Development Mechanism: A Global Analysis of the Impact of Forest Definition. Mitig. Adapt. Strateg. Glob. Change 2007, 13, 219-239. [CrossRef]

20. Gebremedhin, M.A.; Kahsay, G.H.; Fanta, H.G. Assessment of Spatial Distribution of Aridity Indices in Raya Valley, Northern Ethiopia. Appl. Water Sci. 2018, 8, 1-8. [CrossRef]

21. Zomer, R.J.; Trabucco, A.; Bossio, D.A.; Verchot, L.V. Climate Change Mitigation: A Spatial Analysis of Global Land Suitability for Clean Development Mechanism Afforestation and Reforestation. Agric. Ecosyst. Environ. 2008, 126, 67-80. [CrossRef]

22. CGIAR-CSI. Global Aridity and PET Database-CGIAR-CSI. Available online: https:/ / cgiarcsi.community/data/global-aridityand-pet-database/ (accessed on 12 September 2021).

23. Özkan, B.; Dengiz, O.; Turan, İ.D. Site Suitability Analysis for Potential Agricultural Land with Spatial Fuzzy Multi-Criteria Decision Analysis in Regional Scale under Semi-Arid Terrestrial Ecosystem. Sci. Rep. 2020, 10, 1-18. [CrossRef]

24. Charabi, Y.; Gastli, A. PV Site Suitability Analysis Using GIS-Based Spatial Fuzzy Multi-Criteria Evaluation. Renew. Energy 2011, 36, 2554-2561. [CrossRef]

25. Akbari, M.; Neamatollahi, E.; Neamatollahi, P. Evaluating Land Suitability for Spatial Planning in Arid Regions of Eastern Iran Using Fuzzy Logic and Multi-Criteria Analysis. Ecol. Indic. 2019, 98, 587-598. [CrossRef]

26. Ullah, K.M.; Mansourian, A. Evaluation of Land Suitability for Urban Land-Use Planning: Case Study Dhaka City. Trans. GIS 2016, 20, 20-37. [CrossRef]

27. Aldababseh, A.; Temimi, M.; Maghelal, P.; Branch, O.; Wulfmeyer, V. Multi-Criteria Evaluation of Irrigated Agriculture Suitability to Achieve Food Security in an Arid Environment. Sustainability 2018, 10, 803. [CrossRef]

28. Peñacoba-Antona, L.; Gómez-Delgado, M.; Esteve-Núñez, A. Multi-Criteria Evaluation and Sensitivity Analysis for the Optimal Location of Constructed Wetlands (METland) at Oceanic and Mediterranean Areas. Int. J. Environ. Res. Public Health 2021, 18, 5415. [CrossRef] [PubMed]

29. INEGI. Instituto Nacional de Estadística y Geografía. Available online: https:/ / www.inegi.org.mx/ (accessed on 4 February 2021).

30. CONAGUA. Programa Hídrico Regional Visión 2030. Región Hidrológico-Administrativa I Península de Baja California. Available online: www.conagua.gob.mx (accessed on 19 January 2021).

31. CONAGUA. Programa Hídrico Regional Visión 2030. Región Hidrológico-Administrativa II Noroeste. Available online: http:/ / www.conagua.gob.mx/conagua07/publicaciones/publicaciones/2-sgp-17-12n.pdf (accessed on 19 January 2021).

32. CONAGUA. Programa Hídrico Regional Visión 2030. Región Hidrológico-Administrativa III Pacífico Norte. Available online: www.semarnat.gob.mxwww.conagua.gob.mxwww.conagua.gob.mx/conagua07/temas/programashídricosregionales203 0.pdf (accessed on 20 January 2021).

33. Salinas-Zavala, C.A.; Lluch-Belda, D.; Hernández-Vázquez, S.; Lluch-Cota, D.B. La Aridez en el Noroeste de México. Un Análisis de su Variabilidad Espacial y Temporal. Available online: https://www.researchgate.net/publication/236262465_La_aridez_en_ el_Noroeste_de_Mexico_Un_analisis_de_su_variabilidad_espacial_y_temporal (accessed on 23 January 2019).

34. NIDIS. North American Drought Monitor. Available online: https://www.drought.gov/nadm/content/map/2019/09 (accessed on 29 October 2019).

35. Lobato-Sánchez, R. El Monitor de la Sequía en México; Instituto Mexicano de Tecnología del Agua: Jiutepec, Mexico, 2016 ; Volume 7.

36. Verbist, K.; Santibañez, F.; Gabriels, D.; Soto, G. ATLAS de Zonas Áridas de América Latina y el Caribe Elaborado por. Available online: http:/ / www.cazalac.org/mapa_za.php (accessed on 4 February 2019).

37. Gutiérrez, M.; Rodríguez, J. Metodología para la Elaboración del Mapa de Aridez del Estado Nueva Esparta, Venezuela. Available online: https: / / www.redalyc.org/pdf/721/72142329007.pdf (accessed on 20 October 2019).

38. AdapteCCa. Visor de Escenarios de Cambio Climático. Visor de Escenarios de Cambio Climático. 2019. Available online: http: / / escenarios.adaptecca.es / info (accessed on 21 October 2019).

39. CONAGUA; UNAM. Monitor de Sequía Multivariado en México (MoSeMM). Available online: https://www.gob.mx/conagua/ documentos / monitor-de-sequia-multi-parametrico-de-mexico-mosemm?state=published (accessed on 29 October 2019).

40. Kumari, N.; Srivastava, A.; Dumka, U.C. A Long-Term Spatiotemporal Analysis of Vegetation Greenness over the Himalayan Region Using Google Earth Engine. Climate 2021, 9, 109. [CrossRef] 
41. Pei, F.; Zhou, Y.; Xia, Y. Application of Normalized Difference Vegetation Index (NDVI) for the Detection of Extreme Precipitation Change. Forests 2021, 12, 594. [CrossRef]

42. Abatzoglou, J.T.; Dobrowski, S.Z.; Parks, S.A.; Hegewisch, K.C. TerraClimate, a High-Resolution Global Dataset of Monthly Climate and Climatic Water Balance from 1958-2015. Sci. Data 2018, 5, 1-12. [CrossRef]

43. McNally, A.; Arsenault, K.; Kumar, S.; Shukla, S.; Peterson, P.; Wang, S.; Funk, C.; Peters-Lidard, C.D.; Verdin, J.P. A Land Data Assimilation System for Sub-Saharan Africa Food and Water Security Applications. Sci. Data 2017, 4, 1-19. [CrossRef]

44. Monjardin-Armenta, S.A.; Plata-Rocha, W.; Pacheco-Angulo, C.E.; Franco-Ochoa, C.; Peraza, J.G.R. Geospatial Simulation Model of Deforestation and Reforestation Using Multicriteria Evaluation. Sustainability 2020, 12, 387. [CrossRef]

45. Zabihi, H.; Alizadeh, M.; Langat, P.K.; Karami, M.; Shahabi, H.; Ahmad, A.; Said, M.N.; Lee, S. GIS Multi-Criteria Analysis by Orderedweighted Averaging (OWA): Toward an Integrated Citrus Management Strategy. Sustainability 2019, 11, 1009. [CrossRef]

46. Zhang, X.; Fang, C.; Wang, Z.; Ma, H. Urban Construction Land Suitability Evaluation Based on Improved Multi-Criteria Evaluation Based on GIS (MCE-GIS): Case of New Hefei City, China. Chin. Geogr. Sci. 2013, 23, 740-753. [CrossRef]

47. Azareh, A.; Sardooi, E.R.; Choubin, B.; Barkhori, S.; Shahdadi, A.; Adamowski, J.; Shamshirband, S. Incorporating Multi-Criteria Decision-Making and Fuzzy-Value Functions for Flood Susceptibility Assessment. Geocarto Int. 2019, 7, 1-21. [CrossRef]

48. Feizizadeh, B.; Blaschke, T. GIS-Multicriteria Decision Analysis for Landslide Susceptibility Mapping: Comparing Three Methods for the Urmia Lake Basin, Iran. Nat. Hazards 2013, 65, 2105-2128. [CrossRef]

49. Saaty, T.L. A Scaling Method for Priorities in Hierarchical Structures. J. Math. Psychol. 1977, 15, 234-281. [CrossRef]

50. Criado, M.; Martínez-Graña, A.; Santos-Francés, F.; Veleda, S.; Zazo, C. Multi-Criteria Analyses of Urban Planning for City Expansion: A Case Study of Zamora, Spain. Sustainability 2017, 9, 1850. [CrossRef]

51. Saaty, T.L. Decision Making with the Analytic Hierarchy Proces. Int. J. Serv. Sci. 2008, 1, 83-98.

52. Aydi, A. Evaluation of Groundwater Vulnerability to Pollution Using a GIS-Based Multi-Criteria Decision Analysis. Groundw. Sustain. Dev. 2018, 7, 204-211. [CrossRef]

53. Barrow, C.J. World Atlas of Desertification (United Nations Environment Programme). Land Degrad. Dev. 1992, 3, 249. [CrossRef]

54. Cherlet, M.; Hutchinson, C.; Reynolds, J.; Hill, J.; Sommer, S.; von Maltitz, G. World Atlas of Desertification, 3rd ed.; Office of the European Union: Luxembourg, 2018.

55. Saltelli, A.; Tarantola, S.; Chan, K.P.S. A Quantitative Model-Independent Method for Global Sensitivity Analysis of Model Output. Technometrics 1999, 41,39-56. [CrossRef]

56. Del-Toro-Guerrero, F.J.; Kretzschmar, T. Precipitation-Temperature Variability and Drought Episodes in Northwest Baja California, México. J. Hydrol. Reg. Stud. 2020, 27, 100653. [CrossRef]

57. Ortega-Gaucin, D.; Bartolón, J.D.L.C.; Bahena, H.V.C. Drought Vulnerability Indices in Mexico. Water 2018, 10, 1671. [CrossRef]

58. Oertel, M.; Meza, F.J.; Gironás, J.; Scott, C.A.; Rojas, F.; Pineda-Pablos, N. Drought Propagation in Semi-Arid River Basins in Latin America: Lessons from Mexico to the Southern Cone. Water 2018, 10, 1564. [CrossRef]

59. Pontifes, P.A.; Caso-Chávez, M.; García-Meneses, P.M.; Gómez-Aíza, L. Land Use/Land Cover Change and Extreme Climatic Events in the Arid and Semi-Arid Ecoregions of Mexico. Atmósfera 2018, 31, 355-372. [CrossRef]

60. Tabari, H.; Talaee, P.H.; Nadoushani, S.S.M.; Willems, P.; Marchetto, A. A Survey of Temperature and Precipitation Based Aridity Indices in Iran. Quat. Int. 2014, 345, 158-166. [CrossRef]

61. Spinoni, J.; Vogt, J.; Naumann, G.; Carrao, H.; Barbosa, P. Towards Identifying Areas at Climatological Risk of Desertification Using the Köppen-Geiger Classification and FAO Aridity Index. Int. J. Climatol. 2015, 35, 2210-2222. [CrossRef]

62. Global Aridity Index and Potential Evapotranspiration (ET0) Climate Database v2. Available online: https://figshare.com/articles/ Global_Aridity_Index_and_Potential_Evapotranspiration_ET0_Climate_Database_v2/7504448/1 (accessed on 3 October 2021).

63. Li, Y.; Feng, A.; Liu, W.; Ma, X.; Dong, G. Variation of Aridity Index and the Role of Climate Variables in the Southwest China. Water 2017, 9, 743. [CrossRef]

64. Díaz-Padilla, G.; Sánchez-Cohen, I.; Guajardo-Panes, R.A.; Del Ángel-Pérez, A.L.; Ruíz-Corral, A.; Medina-García, G.; IbarraCastillo, D. Mapeo del Índice de Aridez y su Distribución Poblacional en México. Revista Chapingo Ser. Cienc. For. Ambiente 2011, 17, 267-275. [CrossRef]

65. Campos-Aranda, D.F. Estudio de Sequías Meteorológicas Anuales por Medio del Índice de Aridez, en el Estado de Zacatecas, México. Ing. Investig. Tecnol. 2016, 17, 405-417. [CrossRef]

66. INEGI. Climatología. Available online: https:/ /www.inegi.org.mx/temas/climatologia/ (accessed on 14 July 2021).

67. CONABIO. Geoportal del Sistema Nacional de Información Sobre Biodiversidad (14,117)-CONABIO. Available online: http:/ / www.conabio.gob.mx/informacion/gis / (accessed on 14 July 2021). 